\title{
Hubungan antara Kadar Tumor Necrosis Factor-Alpha (TNF- $\alpha$ ) Plasma dengan Kejang Demam Sederhana pada Anak
}

\section{The Relationship between Levels of Tumor Necrosis Factor-Alpha (TNF- $\alpha$ ) Plasma and Simple Febrile Seizures in Children}

\author{
Dewi Nurindah, Masdar Muid, Sumarno Retoprawiro \\ Laboratorium IImu Kesehatan Anak Rumah Sakit Umum Daerah Dr. Saiful Anwar Malang
}

\begin{abstract}
ABSTRAK
Kejang demam adalah penyebab kejang paling umum pada anak dan sering menjadi penyebab rawat inap di rumah sakit secara darurat. Studi pendahuluan pada anak menunjukkan bahwa jaringan sitokin diaktifkan dan mungkin berperan dalam patogenesis kejang demam namun, signifikansi klinis yang tepat masih belum jelas. Penelitian ini bertujuan untuk membuktikan hubungan antara kadar TNF- $\alpha$ plasma dengan kejang demam sederhana. Penelitian cross sectional dilakukan pada Maret-April 2014 di Departemen Ilmu Kesehatan Anak Rumah Sakit Umum dr. Saiful Anwar Malang. Terdapat 38 subjek yang memenuhi kriteria inklusi, 19 pasien kejang demam sederhana dan 19 pasien demam tanpa kejang (usia 6 bulan-5 tahun). Kadar TNF- $\alpha$ plasma diperiksa dengan ELISA. Analisis Independent t test menunjukkan tidak terdapat perbedaan bermakna karakteristik subjek, suhu rektal dan kadar lekosit. Analisis Mann-Whitney menunjukkan tidak terdapat perbedaan bermakna karakteristik subjek jenis kelamin dan kadar CRP. Kejang demam lebih banyak ditemukan pada usia yang lebih muda dibandingkan demam tanpa kejang. Hasil Independent $t$ test juga menunjukkan terdapat perbedaan bermakna antara kadar TNF- $\alpha$ plasma kelompok kejang demam sederhana dan kelompok demam tanpa kejang $(p=0,002)$. Hasil uji Spearman menunjukkan terdapat korelasi negatif sedang yang bermakna antara kadar TNF- $\alpha$ plasma kelompok kejang demam sederhana dan kelompok demam tanpa kejang $(r=-0,533 ; p=0,001)$. Dapat disimpulkan bahwa terdapat hubungan antara kadar TNF- $\alpha$ plasma dengan terjadinya kejang demam sederhana.
\end{abstract}

Kata Kunci: Anak, kejang demam sederhana, TNF- $\alpha$ plasma

\begin{abstract}
Febrile seizures are the most common cause of convulsions in children and frequently cause hospitalization on emergency basis. Preliminary studies in children suggest that the cytokine network is activated and may have a role in the pathogenesis of febrile seizures, but the precise clinical significance remains unclear. This study aims to establish a relationship between plasma levels of TNF- $\alpha$ and simple febrile seizures. Cross-sectional study was conducted from March to April 2014 at Department of Pediatrics Saiful Anwar Hospital. There were 38 samples that met the inclusion criteria; 19 patients of simple febrile seizures and 19 patients of febrile without seizures (ages 6 months to 5 years). Plasma levels of TNF- $\alpha$ were examined with ELISA. Independent $t$ test analysis showed no significant differences in subject characteristics, rectal temperature and leukocyte levels. Mann-Whitney analysis showed no significant differences in subject characteristics of gender and CRP levels. Simple febrile seizures are more common in younger age than febrile without seizures. Independent t test results also show that there are significant differences between plasma levels of TNF- $\alpha$ simple febrile seizures group and febrile without seizures group ( $p=0,002)$. Spearman's test results show there is a significant negative correlation between plasma levels of TNF- $\alpha$ group of simple febrile seizures and febrile without seizures group $(r=-0,533, p=0,001)$. It can be concluded that there is a relationship between plasma levels of TNF- $\alpha$ with simple febrile seizures.
\end{abstract}

Keywords: Children, simple febrile seizures, TNF- $\alpha$ plasma

Jurnal Kedokteran Brawijaya, Vol. 28, No. 2, Agustus 2014; Korespondensi: Dewi Nurindah. Laboratorium Ilmu Kesehatan Anak Rumah Sakit Umum Daerah Dr. Saiful Anwar Malang, Jl. Jaksa Agung Suprapto No. 2 Malang Tel. (0341) 366242 Email: dewideden@gmail.com 


\section{PENDAHULUAN}

Kejang demam adalah penyebab kejang paling umum pada anak dan sering menjadi penyebab rawat inap di rumah sakit secara darurat (1). Kejang demam didefinisikan sebagai kejang pada anak usia 6 bulan sampai 5 tahun disertai demam, tanpa bukti infeksi sistem saraf pusat yang mendasari. Puncak kejang demam terjadi pada usia 18 bulan (2). Kejang demam adalah bentuk paling umum dari kejang masa kanak-kanak, terjadi pada 2-5\% anak di Amerika Serikat (3). Di Eropa dan Amerika Serikat $2-5 \%$ anak (lebih sering terjadi pada anak laki-laki) mengalami setidaknya satu kali kejang demam sebelum usia 5 tahun. Meski studi pendahuluan di India menyebutkan hingga $10 \%$ anak mengalami kejang demam, data terakhir menunjukkan bahwa angka kejadian di India mirip dengan di Barat (1). Kejang demam terjadi pada 2-4\% anak di Indonesia (4).

Diagnosis kejang demam pada dasarnya berdasarkan temuan klinis dan deskripsi yang diberikan oleh orangtua. Meskipun sebagian besar kejang demam adalah ringan dan terkait dengan penyakit virus yang ringan, sangat penting bahwa anak segera dievaluasi untuk mengurangi kecemasan orangtua dan untuk mengidentifikasi penyebab demam (1). Kejang demam sederhana adalah kejang general (tanpa gerakan fokal) yang berlangsung kurang dari 15 menit dan hanya terjadi sekali selama periode 24 jam dari demam pada anak yang secara neurologis normal (1). Sebagian besar kejang demam adalah kejang demam sederhana, namun kejang demam dengan onset fokal, durasi berkepanjangan, atau yang terjadi lebih dari sekali pada penyakit demam yang sama dianggap sebagai kejang demam kompleks (3). Setelah kejang demam awal (sederhana atau kompleks), tiga sampai dua belas persen anak berkembang menjadi epilepsi saat remaja (1).

Patofisiologi kejang demam masih belum jelas, tetapi faktor genetik memainkan peran utama dalam kerentanan kejang. Kejadian kejang demam dipengaruhi oleh usia dan maturitas otak. Postulat ini didukung oleh fakta bahwa sebagian besar (80-85\%) kejang demam terjadi antara usia 6 bulan dan 5 tahun, dengan puncak insiden pada 18 bulan. Meskipun mekanisme peningkatan kerentanan ini tidak jelas, model hewan menunjukkan bahwa terdapat peningkatan eksitabilitas neuron selama maturasi otak normal. Studi pendahuluan pada anak menunjukkan bahwa jaringan sitokin diaktifkan dan mungkin memiliki peran dalam patogenesis kejang demam. Meskipun demikian, signifikansi klinis yang tepat dari penelitian ini masih belum jelas (1).

Sistem imunitas tubuh dan sistem saraf perifer serta sentral selalu berkomunikasi melalui perantara dan sinyal molekul yang dikeluarkan, seperti sitokin, neuropeptida, neurohormon dan neurotransmiter. Kejang didefinisikan sebagai tampaknya tanda dan gejala yang memicu aktivitas neuron abnormal yang berlebihan di otak. Sistem saraf pusat, melalui blood-brain barrier, membatasi aliran sel-sel yang diaktifkan dan mediator-mediator inflamasi yang dilepaskan dari sistem perifer menuju parenkim otak. Kejang tidak hanya menginduksi ekspresi sitokin di dalam otak, tetapi juga di perifer (5). Bukti terbaru menunjukkan bahwa molekul pro-inflamasi dan antiinflamasi disintesis selama aktivitas epileptik pada sel-sel glial di daerah sistem saraf pusat dimana kejang dimulai dan menyebar. Molekul-molekul ini dikeluarkan dan berinteraksi dengan reseptor spesifik pada neuron.
Karena berbagai sitokin telah ditunjukkan mempengaruhi eksitabilitas neuron, hal ini menyebabkan hipotesis bahwa sitokin mungkin berperan dalam mengubah transmisi sinaptik dalam kondisi epileptik. Studi ini menunjukkan bahwa molekul pro-inflamasi dan anti-inflamasi lainnya yang dihasilkan dalam sistem saraf pusat mungkin berperan dalam patofisiologi kejang (6). Aktivasi jaringan sitokin pro-inflamasi dan anti-inflamasi tampaknya berperan dalam kejang demam (7).

Menurut Haberlandt pasien kejang demam mengalami peningkatan konsentrasi TNF- $\alpha$ plasma secara signifikan dibandingkan pasien dengan demam saja (8). Menurut Choi kadar TNF- $\alpha$ serum tidak berbeda antara pasien kejang demam dan kontrol hanya demam (9). Dari beberapa penelitian terdahulu masih perlu dilakukan penelitian untuk memastikan kadar TNF- $\alpha$ plasma sebagai biomarker dalam memprediksi terjadinya kejang demam. Tujuan dari penelitian ini adalah untuk membuktikan hubungan antara kadar TNF- $\alpha$ plasma dengan terjadinya kejang demam sederhana.

\section{METODE}

Dilakukan penelitian cross sectional dengan pengambilan sampel consecutive sampling pada bulan Maret sampai April 2014 pada pasien kejang demam sederhana dan pasien demam tanpa kejang yang memenuhi kriteria inklusi di Departemen Ilmu Kesehatan Anak Rumah Sakit Umum Dr. Saiful Anwar Malang. Kriteria inklusi adalah kejang demam sederhana, usia 6 bulan sampai 5 tahun, suhu rektal $>38^{\circ} \mathrm{C}$, darah diambil $<12$ jam dari awal kejang, inform concent dari orangtua pasien, dan tidak ada penyebab lain dari kejang selain demam. Berdasarkan hasil perhitungan besar sampel maka diperoleh minimal sampel adalah 19 pasien untuk setiap kelompok (10). Terdapat 38 sampel terdiri dari 19 pasien kejang demam sederhana dan 19 pasien demam tanpa kejang. Pengambilan sampel darah dilakukan saat pasien datang di Instalasi Gawat Darurat Rumah Sakit Umum dr. Saiful Anwar Malang. Pengambilan dilakukan oleh paramedis yang terlatih. Volume darah yang diambil $2 \mathrm{ml}$ dicampur dengan EDTA sebagai antikoagulan. Sampel darah segar disimpan dalam cool box, dipertahankan suhunya $4^{\circ} \mathrm{C}$ dan dengan segera dikirim ke Laboratorium Biomedik Fakultas Kedokteran Universitas Brawijaya Malang untuk diperiksa kadar TNF- $\alpha$ dengan cara ELISA.

Variabel yang diamati adalah kadar TNF- $\alpha$ pada pasien kejang demam sederhana dan pasien demam tanpa kejang. Kadar TNF- $\alpha$ plasma diukur dengan teknik ELISA dengan satuan $\mathrm{pg} / \mathrm{ml}$. Data kadar TNF- $\alpha$ dilakukan uji normalitas data. Hasil uji normalitas data digunakan sebagai dasar menentukan uji statistik untuk mengetahui adanya perbedaan dan korelasi kadar TNF- $\alpha$. Jika sebaran data normal, maka digunakan uji Independent $t$ test. Jika sebaran data tidak normal, maka digunakan uji MannWhitney. Selanjutnya digunakan uji korelasi Spearman. Dianggap bermakna bila nilai $p<0,05$ (11). Analisis statistik diolah dengan SPSS 15.

\section{HASIL}

Pada penelitian ini didapatkan 38 subjek dalam 2 kelompok yaitu 19 pasien dalam kelompok kejang demam sederhana dan 19 pasien dalam kelompok demam tanpa kejang. Data karakteristik dasar subjek penelitian pada kelompok kejang demam sederhana dan kelompok 
demam tanpa kejang tertera pada Tabel 1.

Tabel 1 menunjukkan bahwa kelompok kejang demam sederhana mayoritas berjenis kelamin laki-laki yaitu 13 dari 19 anak, sedangkan kelompok demam tanpa kejang mayoritas berjenis kelamin perempuan yaitu 10 dari 19 anak. Rerata usia pada kelompok kejang demam sederhana adalah 20,68 bulan dan pada kelompok demam tanpa kejang adalah 35,47 bulan. Rerata suhu rektal pada kelompok kejang demam sederhana adalah $38,79^{\circ} \mathrm{C}$, sedangkan pada kelompok demam tanpa kejang adalah $38,81^{\circ} \mathrm{C}$. Rerata leukosit pada kelompok kejang demam sederhana adalah $9.200 \mathrm{mg} / \mathrm{dl}$ dan kelompok demam tanpa kejang adalah $8.517 \mathrm{mg} /$ dl. Rerata CRP pada kelompok kejang demam sederhana adalah 0,98 mg/dl, sedangkan pada kelompok demam tanpa kejang adalah $0,69 \mathrm{mg} / \mathrm{dl}$. Secara keseluruhan tidak ditemukan perbedaan bermakna karakeristik dasar subjek pada kelompok kejang demam sederhana dan demam tanpa kejang kecuali pada faktor usia. Pada kelompok demam tanpa kejang mempunyai usia yang lebih tinggi secara bermakna dibandingkan kelompok kejang demam sederhana. Kadar TNF- $\alpha$ pada kelompok kejang demam sederhana lebih tinggi secara bermakna $(8,14 \pm 4,40$, $\mathrm{p}=0,002$ ) dibandingkan kelompok demam tanpa kejang $(4,08 \pm 2,54)$. Hasil uji korelasi Spearman menunjukkan terdapat korelasi negatif sedang yang bermakna antara kadar TNF- $\alpha$ plasma kelompok kejang demam sederhana dengan kelompok demam tanpa kejang ( $r=-0,533$; $p=0,001)$.

Tabel 1. Perbedaan karakteristik subjek, gambaran klinis dan kadar TNF- $\alpha$

\begin{tabular}{|c|c|c|c|}
\hline Karakteristik dasar & $\begin{array}{c}\text { Kejang demam } \\
\text { sederhana } \\
(n=19)\end{array}$ & $\begin{array}{c}\text { Demam tanpa } \\
\text { kejang } \\
(n=19)\end{array}$ & $\begin{array}{c}\text { Uji } \\
\text { Komparasi }\end{array}$ \\
\hline Jenis kelamin & & & $* 0,271$ \\
\hline Laki-laki & $13 / 19$ & $9 / 19$ & \\
\hline Perempuan & $6 / 19$ & $10 / 19$ & \\
\hline $\begin{array}{l}\text { Rerata usia, } x \pm S D \\
\text { (bulan) }\end{array}$ & $20,68 \pm 12,69$ & $3547 \pm 23,23$ & 0,022 \\
\hline $\begin{array}{l}\text { Rerata suhu rektal saat } \\
\text { kejang, } x \pm S D\left({ }^{\circ} \mathrm{C}\right)\end{array}$ & $38,78 \pm 0,67$ & $38,81 \pm 0,55$ & 0,896 \\
\hline $\begin{array}{l}\text { Rerata leukosit, } x \pm S D \\
(\mathrm{mg} / \mathrm{dl})\end{array}$ & $9200 \pm 3827$ & $8517 \pm 4257$ & 0,606 \\
\hline $\begin{array}{l}\text { Rerata CRP, } x \pm S D \\
(\mathrm{mg} / \mathrm{dl})\end{array}$ & $0,98 \pm 1,58$ & $0,69 \pm 0,67$ & $* 0,686$ \\
\hline Rerata kadar TNF- $\alpha$ & $8,14 \pm 4,40$ & $4,08 \pm 2,54$ & 0,002 \\
\hline
\end{tabular}

Keterangan: *uji Mann Whitney

\section{DISKUSI}

Pada penelitian ini didapatkan kejang demam lebih banyak terjadi pada anak laki-laki yaitu 13 anak (68,42\%) dari 19 anak. Hasil uji statistik menunjukkan tidak terdapat perbedaan bermakna jenis kelamin antara pasien yang mengalami kejang demam sederhana dan demam tanpa kejang. Penelitian ini sesuai dengan Millar bahwa anak laki-laki sedikit lebih sering mengalami kejang demam daripada anak perempuan (12). Hal ini mungkin disebabkan karena maturasi sel pada anak perempuan lebih cepat daripada anak laki-laki, termasuk maturasi pada sel saraf.
Hasil uji statistik menunjukkan terdapat perbedaan usia antara pasien yang mengalami kejang demam sederhana dan demam tanpa kejang. Penelitian ini sesuai dengan Fuadi et al bahwa usia <2 tahun saat pertama kali kejang merupakan faktor resiko terjadinya kejang demam secara bermakna, usia $<2$ tahun memiliki resiko 3,4 kali lipat menderita kejang demam (13). Usia <2 tahun merupakan masa developmental window (masa perkembangan otak fase organisasi). Pada masa developmental window keadaan otak belum matang, pada otak yang belum matang regulasi ion $\mathrm{Na}^{+}, \mathrm{K}^{+}$, dan $\mathrm{Ca}^{2+}$ belum sempurna sehingga mengakibatkan gangguan repolarisasi pasca depolarisasi dan meningkatkan eksitabilitas neuron (14). Corticotropin releasing hormon ( $\mathrm{CRH}$ ) merupakan neuropeptid eksitator, berpotensi sebagai prokonvulsan. Pada otak belum matang kadar $\mathrm{CRH}$ di hipokampus tinggi, berpotensi untuk terjadi bangkitan kejang apabila terpicu oleh demam. Mekanisme homeostatis pada otak belum matang masih lemah, akan berubah sejalan dengan perkembangan otak dan pertambahan usia, oleh karena pada otak belum matang neural $\mathrm{Na}^{+} / \mathrm{K}^{+}$ATP ase masih kurang. Anak yang mendapat bangkitan kejang demam pada umur awal masa developmental window mempunyai fase eksitabilitas neural lebih lama dibanding anak yang mendapat bangkitan kejang demam pada umur akhir masa developmental window (13). Pada masa otak belum matang eksitasi lebih dominan dibanding inhibisi. Masa ini disebut masa developmental window yang rentan terhadap bangkitan kejang. Oleh karena itu bila anak mengalami demam pada fase eksitabilitas otak akan memudahkan bangkitan kejang terjadi.

Hasil uji statistik menunjukkan tidak terdapat perbedaan suhu rektal antara pasien yang mengalami kejang demam sederhana dan demam tanpa kejang. Penelitian ini sesuai dengan Yuana bahwa suhu bukan merupakan faktor risiko terjadinya kejang demam. Suhu badan saat timbul bangkitan kejang demam pertama pada pasien dengan mutasi gen adalah lebih rendah dibandingkan pasien tanpa mutasi gen $\left(38^{\circ} \mathrm{C}\right.$ dibanding $\left.39^{\circ} \mathrm{C}\right)$. Pasien dengan mutasi gen memiliki ambang kejang rendah akibat adanya channelopathy. Channelopathy dapat mengakibatkan temperature sensitive sehingga dengan suhu tidak tinggi sudah terjadi bangkitan kejang demam (15). Oleh karena itu suhu tidak dapat dijadikan acuan untuk terjadinya kejang demam sederhana. Suhu anak dapat tinggi atau rendah saat timbulnya kejang demam, tergantung faktor yang mendasari seperti adanya mutasi gen.

Hasil uji statistik menunjukkan tidak terdapat perbedaan kadar leukosit antara pasien yang mengalami kejang demam sederhana dan demam tanpa kejang. Penelitian ini sesuai dengan Utama bahwa leukosit tidak dapat sebagai prediktor yang baik adanya infeksi bakteri pada anak dengan demam yang tidak diketahui penyebabnya (16). Castelli et al juga mengemukakan bahwa marker tradisional seperti hitung leukosit adalah tidak spesifik (17). Iskandar juga menyebutkan bahwa hitung leukosit tidak dapat digunakan untuk memprediksi infeksi bakterial pada pasien sindrom syok dengue di Pediatric Intensive Care Unit (PICU) (18). Patut disadari bahwa peningkatan leukosit (leukositosis) tidak selalu disebabkan oleh karena adanya infeksi bakteri. Leukositosis secara primer bisa disebabkan oleh gangguan pada bone marrow seperti leukemia atau limfoma, secara sekunder baru disebabkan oleh kondisi abnormal sumsum tulang seperti adanya infeksi bakteri yang sering disebut reaktif leukositosis. 
Peningkatan leukosit mungkin disebabkan oleh peningkatan neutrofil atau eosinofil. Beberapa penyebab leukositosis adalah neutrofilia (infeksi akut, inflamasi dan nekrosis jaringan), eosinofilia (alergi, parasit), monositosis (infeksi kronik, gangguan inflamasi), basofilia (cacar air), limfositosis (infeksi akut oleh mononukleosis, infeksi kronik misalnya tuberkulosis) (16). Selain faktor genetik, faktor lingkungan (infeksi bakteri maupun virus), ternyata juga terbukti memberikan kontribusi pada patofisiologi kejang demam. Hal tersebut mulai diteliti setelah ditemukan fakta bahwa pada kondisi hipertermia karena infeksi ternyata mampu memprovokasi timbulnya episode kejang pada sebagian besar populasi. Penelitian menunjukkan bahwa pada populasi demam dengan kejang, RNA virus mampu merangsang leukosit menstimulasi peningkatan kadar IL-1ß secara bermakna jika dibanding dengan populasi demam tanpa kejang. Kejang demam diduga terjadi karena IL-1 $\beta$ menginduksi kondisi hipertermia yang dapat memicu kejang (19). Oleh karena itu leukosit tidak dapat dijadikan marker untuk terjadinya kejang demam sederhana. Leukosit yang tinggi, nomal, atau rendah dapat terjadi pada kejang demam sederhana. Hal ini sesuai bahwa faktor genetik dan lingkungan (infeksi bakteri maupun virus) dapat berperan dalam kejang demam sederhana.

Hasil uji statistik menunjukkan tidak terdapat perbedaan kadar CRP antara pasien yang mengalami kejang demam sederhana dan demam tanpa kejang. Penelitian ini sesuai dengan Utama bahwa nilai CRP tidak dapat sebagai prediktor yang baik adanya infeksi bakteri pada anak dengan demam yang tidak diketahui penyebabnya (16). Iskandar juga menyebutkan bahwa CRP tidak dapat digunakan untuk memprediksi infeksi bakterial pada pasien sindrom syok dengue di PICU (18). CRP merupakan protein pentamer siklik $115 \mathrm{kDa}$ yang terdiri dari 5 protomer. Masing-masing protomer terdiri dari 206 asam amino. Dinamakan $C$-reactive protein karena mempunyai kemampuan untuk mengikat somatic $C$ polisakarida dari Streptococcus pneumonia (18). CRP merupakan protein fase akut yang dibentuk di hati (oleh sel hepatosit) akibat adanya proses peradangan atau infeksi. Setelah terjadi peradangan, pembentukan CRP akan meningkat 4 sampai 6 jam, jumlahnya bahkan berlipat dua dalam 8 jam setelah peradangan. Konsentrasi puncak akan tercapai dalam 36 jam sampai 50 jam setelah inflamasi. Kadar CRP akan terus meningkat seiring dengan proses inflamasi yang akan mengakibatkan kerusakan jaringan. Apabila terjadi penyembuhan akan terjadi penurunan kadar CRP secara

\section{DAFTAR PUSTAKA}

1. Karande S. Febrile Seizures: A Review for Family Physicians. Indian Journal of Medical Sciences. 2007; 61(3): 161-172.

2. Srinivasan J, Wallace KA, and Scheffer IE. Febrile Seizures. Australian Family Physician. 2005; 34(12): 1021-1025.

3. Shinnar S and Glauser TA. Febrile Seizures. Journal of Child Neurology. 2002; 17(Suppl1): S44-S52.

4. Pusponegoro HD, Widodo DP, and Ismael S. Konsensus Penatalaksanaan Kejang Demam. Jakarta: Badan Penerbit IDAl; 2006; hal. 1-9.

5. Velasco-Ramirez SF, Rosales-Rivera LY, Ramirez- cepat karena CRP memiliki masa paruh 4 sampai 7 jam. Kinetik metabolisme CRP sejalan dengan derajat peradangan dan derajat penyembuhan yang terjadi (16). Oleh karena itu CRP tidak dapat dijadikan marker untuk terjadinya kejang demam sederhana. Infeksi bakteri dapat terjadi pada kejang demam sederhana maupun pada demam tanpa kejang sehingga CRP dapat meningkat pada dua kondisi ini.

Rerata kadar TNF- $\alpha$ plasma pada kejang demam sederhana lebih tinggi dari demam tanpa kejang. Hasil uji statistik menunjukkan terdapat perbedaan kadar TNF- $\alpha$ antara pasien yang mengalami kejang demam sederhana dan demam tanpa kejang. Selain itu ada hubungan yang signifikan antara karakter klinis dengan kadar TNF- $\alpha$. Sesuai grafik linieritas, pasien yang mengalami kejang demam sederhana cenderung diikuti oleh kadar TNF- $\alpha$ yang lebih tinggi daripada kadar TNF- $\alpha$ pada pasien yang hanya mengalami demam tanpa kejang. Penelitian ini sesuai dengan Haberlandt bahwa konsentrasi TNF- $\alpha$ meningkat signifikan pada.anak dengan kejang demam dibanding anak dengan demam (8). Temuan berbeda didapatkan oleh Choi yang membuktikan tidak ada perbedaan kadar TNF- $\alpha$ serum antara pasien kejang demam dan kontrol hanya demam (9). Hal ini dapat disebabkan karena waktu pengambilan sampel pada penelitian ini dilakukan dengan tepat (hingga 12 jam setelah kejang demam) sesuai dengan peningkatan kadar TNF- $\alpha$. Pada penelitian sebelumnya sampel diambil 30 menit setelah kejang demam, masih mungkin peningkatan kadar TNF- $\alpha$ belum optimal. TNF- $\alpha$ berperan dalam kejang demam melalui reseptor AMPA dan melalui COX-2. Berdasar penelitian ini TNF- $\alpha$ dapat menjadi biomarker untuk terjadinya kejang demam sederhana atau kejang demam berulang. Keterbatasan penelitian ini adalah tidak dilakukannya pengendalian faktor perancu seperti riwayat nutrisi dan riwayat terapi sebelumnya. Hal ini sesuai dengan kondisi klinis nyata yaitu adanya keterlibatan multifaktor sebagai penyebab kejang demam.

Penelitian ini membuktikan bahwa usia pada pasien kejang demam sederhana lebih muda dibanding usia pada pasien demam tanpa kejang. Disarankan memberikan edukasi kepada orangtua, jika anak berusia $<2$ tahun mengalami demam diharapkan untuk waspada akan bangkitan kejang demam untuk menurunkan morbiditas dan juga untuk menghindari dampak buruk bangkitan kejang demam pada anak. Kadar TNF- $\alpha$ tampak berperan dalam terjadinya kejang demam sederhana dan berpotensi sebagai biomarker terjadinya kejang demam sederhana.

Anguiano AC, and Bitzer-Quintero OK. Cytokines and the Nervous System: The Relationship between Seizures and Epilepsy. Reviews Neurology. 2013; 57(4): 171-177.

6. Vezzani A, Moneta D, Richichi C, Perego C, and De Simoni MG. Functional Role of Proinflammatory and Anti-Inflammatory Cytokines in Seizures. Advances in Experimental Medicine and Biology. 2004; 548: 123133.

7. Saghazadeh A, Gharedaghi M, Meysamie A, Bauer S, and Rezaei N. Proinflammatory and Antiinflammatory Cytokines in Febrile Seizures and Epilepsy: Systematic Review and Meta-analysis. Revista de Neurologia. 2014; 25: 281-305. 
8. Haberlandt E, Rauchenzauner M, Morass M, SchollBuergi S, Rostásy K, and Karall D. Proinflammatory Cytokines in Children with Febrile Seizures. Neuropediatrics. 2008; 39: V11.

9. Choi J, Min HJ, and Shin JS. Increased Levels of HMGB1 and Pro-Inflammatory Cytokines in Children with Febrile Seizures. Journal of Neuroinflammation. 2011; 8: 135-144.

10. Dahlan MS. Besar Sampel dan Cara Pengambilan Sampel dalam Penelitian Kedokteran dan Kesehatan. Jakarta: Salemba Medika; 2009; hal. 21-68.

11. Dahlan MS. Statistik untuk Kedokteran dan Kesehatan. Jakarta: Salemba Medika; 2004; hal. 4-27.

12. Millar JS. Evaluation and Treatment of the Child with Febrile Seizure. American Family Physician. 2006; 73(10): 1761-1764.

13. Fuadi, Bahtera T, dan Wijayahadi N. Faktor Risiko Bangkitan Kejang Demam pada Anak. Sari Pediatri. 2010; 12(3): 140-149.

14. Fisher RS and Wu J. Basic Electrophysiology of Febrile Seizures. In: Baram TZ and Shinnar S (Eds). Febrile Seizures. San Diego: Academic Press; 2002: p. 231247.
15. Iva-Yuana, Bahtera T, dan Wijayahadi N. Korelasi Kadar Seng Serum dan Bangkitan Kejang Demam. Sari Pediatri. 2010; 12(3): 150-156.

16. Utama IMGDL. Uji Diagnostik C-Reactive Protein, Leukosit, Nilai Total Neutrofil, dan Suhu pada Anak Demam dengan Penyebab yang Tidak Diketahui. Sari Pediatri. 2012; 13(6): 412-419.

17. Castelli GP, Pognani C, Meisner M, Stuani A, Bellomi D, and Sgarbi L. Procalcitonin and C-Reactive Protein during Systemic Inflammatory Response Syndrome, Sepsis and Organ Dysfunction. Critical Care. 2004; 8(4): R234-R242.

18. Iskandar HR, Pudjiadi A, Mulyo D, Pratiwi A, dan Suryatin Y. Sensitifitas dan Spesifisitas Pemeriksaan Procalcitonin, C-Reactive Protein (CRP), dan Hitung Leukosit untuk Memprediksi Infeksi Bakterial pada Sindrom Syok Dengue di Pediatric Intensive Care Unit. Sari Pediatri. 2010; 12(4): 99-102.

19. Matsuo M, Sasaki K, Ichimaru T, Nakazato S, and Hamasaki Y. Increased IL-1beta Production from dsRNA-Stimulated Leukocytes in Febrile Seizures. Pediatric Neurology. 2006; 35(2): 102-106. 